\title{
Kerk, staat en religieonderwijs
}

\author{
Leni Franken*
}

\section{Summary}

In Belgium and in the Netherlands, religious education (RE) in state schools as well as in faith-based schools is organized by the (recognized) religious communities/schools and not by the state. Although RE is in both countries largely secularized and pluralized, it is officially organized in a denominational way. This is different in Scandinavia and in the UK, where the state is responsible for RE which is, accordingly, non-denominational. Also in France and in Luxembourg is the situation different, as RE is no part of the state school curriculum in these nations. In this contribution, I will illustrate how these different RE models are largely influenced by different church-state relations. In order to do so, I will make a distinction between (1) Lutheran and Anglican nations (non-denominational and non-confessional RE); Roman-Catholic nations with a strict separation between church and state (no RE as a separate school subject); and Roman-Catholic and mixed (Catholic + Lutheran/Calvinist) nations with a regime of 'mutual independence' between church and state (denominational and often also confessional $R E)$. In a final part, I will illustrate how both in Belgium and in the Netherlands $R E$ policy can change in a more pragmatic way, without institutional changes of their respective church-state regimes. Therefore three strategies are mentioned: (1) denominational and non-confessional RE; (2) a core curriculum RE; and (3 creative constitutional interpretations.

\section{Inleiding}

Lange tijd was religieonderwijs op de openbare scholen in Europa overwegend christelijk. Onder meer door de secularisering en toenemende diversiteit is dit mono-confessionele model in verschillende landen geëvolueerd naar een multi-confessioneel model: naast christelijk godsdienstonderwijs wordt er ook onderwijs in andere - door de overheid erkende - religies en niet-confessionele levensbeschouwingen aangeboden. Dat is bijvoorbeeld

\footnotetext{
* Leni Franken is als onderwijsbegeleider verbonden aan het Centrum Pieter Gillis, Universiteit Antwerpen, België.
} 
het geval op de openbare scholen in Nederland en België. Daarnaast zijn een aantal landen overgeschakeld op niet-confessioneel religieonderwijs: zo heeft het luthers godsdienstonderwijs op de openbare scholen in Noorwegen en Zweden plaatsgemaakt voor niet-confessioneel onderwijs over diverse levensbeschouwingen en werd het anglicaans godsdienstonderricht op openbare scholen in het Verenigd Koninkrijk vervangen door een algemeen vormend vak over diverse levensbeschouwingen. Tot slot zijn er ook een aantal landen (Frankrijk en Luxemburg) waar godsdienstonderwijs - hetzij confessioneel, hetzij niet-confessioneel - niet langer als apart schoolvak op het curriculum van de openbare school staat.

In deze bijdrage bespreek ik hoe deze drie evoluties verklaard kunnen worden vanuit de respectievelijke kerk-staat verhoudingen in de betreffende landen. Omdat deze kerk-staat verhoudingen vaak grondwettelijk verankerd zijn, is het niet altijd eenvoudig om het beleid inzake levensbeschouwelijk onderwijs te wijzigen zonder deze verhoudingen (en dus vaak ook de grondwet) te wijzigen. Dit is één van de redenen waarom er in een aantal landen, waaronder België en Nederland, eerder pragmatisch wordt omgegaan met het levensbeschouwelijk onderwijs op school en er gezocht wordt naar alternatieven die beter tegemoet komen aan de levensbeschouwelijk gekleurde schoolpopulatie, zonder daarbij verregaande institutionele wijzigingen door te voeren.

Deze bijdrage richt zich hoofdzakelijk op het religieonderwijs op openbare scholen. ${ }^{1}$ Echter, wanneer wordt ingezoomd op België en Nederland wordt er, gezien het grote aantal bijzondere scholen ${ }^{2}$ daar, ook aandacht besteed aan het bijzonder onderwijs en de manier waarop daar met religieonderwijs wordt omgegaan. De tekst is als volgt opgebouwd: in een eerste luik (\$2) wordt ingegaan op de vrijheid van onderwijs in België en Nederland en op de gevolgen hiervan voor de organisatie van levensbeschouwelijke vakken op bijzondere en openbare scholen. Vervolgens $\left(\mathbb{\int} 3\right)$ bespreek ik drie manieren waarop religieonderwijs op de openbare school in diverse Europese landen wordt georganiseerd en illustreer ik hoe deze drie types van religieonderwijs schatplichtig zijn aan drie verschillende kerk-staat modellen $(\$ 4)$. In $\$ 5$ en $\$ 6$ keer ik weer terug naar België en Nederland en bespreek ik hoe daar, binnen het bestaande kerk-staat systeem en binnen de marges van de vrijheid van onderwijs, op een pragmatische manier wordt omgegaan met het religieonderwijs op school. 


\section{Vrijheid van onderwijs en godsdienstlessen in België en Nederland}

In een liberale democratie heeft ieder mens recht op onderwijs en hebben ouders het recht hun kinderen "van die opvoeding en van dat onderwijs te verzekeren, die overeenstemmen met hun eigen godsdienstige en filosofische overtuigingen" (EVRM, art. 2 protocol 1). Om dit recht niet enkel formeel maar ook substantieel mogelijk te maken, zetten zowel België als Nederland sterk in op de vrijheid van onderwijs: in beide landen is die vrijheid niet alleen grondwettelijk verankerd', maar worden 'vrije' of 'bijzondere' scholen en 'officiële' of 'openbare' scholen op gelijke basis door de overheid gefinancierd. Dit heeft ertoe geleid dat zowel in België als in Nederland het onderwijs verzuild is georganiseerd en de meeste onderwijsverstrekkers er behoren tot het bijzondere of vrije net. ${ }^{4}$

Bijzondere scholen worden onder meer gekenmerkt door de vrijheid van stichting (het oprichten van een school ligt niet enkel bij de overheid, maar kan ook liggen bij privaatrechtelijke rechtspersonen zoals levensbeschouwelijke groeperingen); de vrijheid van richting (bijzondere scholen hebben het recht om in het onderwijs uitdrukking te geven aan hun levensbeschouwelijke, ideologische en/of pedagogische overtuiging, terwijl openbare scholen gebonden zijn aan neutraliteit) ; en de vrijheid van inrichting (bijzondere scholen zijn vrij te kiezen voor een eigen onderwijskundig of pedagogisch concept of voor een eigen rechtsvorm zoals een stichting of vereniging). ${ }^{6}$

Om de vrijheid van richting in de verf te zetten, kunnen bijzondere scholen onder meer confessioneel godsdienstonderwijs aanbieden. Zo volgen alle leerlingen in het katholiek onderwijs in België het vak 'Rooms-katholieke' godsdienst, dat 2 tot 3 uur op het curriculum staat. In de Vlaamse Gemeenschap is de 'Erkende Instantie Rooms-Katholieke Godsdienst' verantwoordelijk voor de organisatie en inspectie van dit vak, de leerplannen (die hetzelfde zijn op alle scholen, openbaar en bijzonder), het lesmateriaal en de aanstelling van lesgevers. Deze moeten niet alleen over het juiste diploma beschikken, maar moeten ook gedoopt zijn en een mandaat (missio) van de kerk krijgen. In de Franse en Duitse Gemeenschappen is het systeem gelijkaardig.?

Ook in Nederland hebben bijzondere scholen de vrijheid om godsdienstles(sen) aan te bieden. Anders dan in België, gaat het er echter minder gecentraliseerd, en bijgevolg ook gediversifieerder, aan toe. Zo is het verzuilde onderwijsmodel op zich al erg gevarieerd: naast de katholieke en openbare scholen zijn bijvoorbeeld ook protestants-christelijke scholen en andere bijzondere scholen, waaronder een toenemend aantal islamitische scholen, 
belangrijke spelers in het onderwijsveld. Bovendien kunnen scholen die officieel tot 'dezelfde' onderwijsverstrekker (bv. katholiek; protestants-christelijk) worden gerekend, heel divers zijn. Dit alles vertaalt zich onder meer in een uiteenlopend aanbod van religieonderwijs: conform de vrijheid van richting kunnen bijzondere scholen ervoor kiezen om sterk in te zetten op de religieuze socialisatie van leerlingen en hiertoe kunnen ze godsdienstonderwijs op een traditionele en confessionele manier aanbieden. Dit gebeurt onder meer in gereformeerde en islamitische scholen. Maar bijzondere scholen kunnen er eveneens voor kiezen om een zo divers mogelijk leerlingenpubliek aan te spreken en hiertoe het confessionele minder of niet te benadrukken. Op deze seculariseringstendens van het godsdienstonderwijs, die we onder meer in katholieke scholen terugvinden, zal ik verderop terugkomen.

Wat het openbaar onderwijs betreft, zien we eveneens dat er in België en Nederland ruimte is voor levensbeschouwing op school: hoewel openbare scholen in beide landen 'neutraal' dienen te zijn en dus geen voorkeur mogen hebben voor een bepaalde levensbeschouwing of religie, is het mogelijk om er godsdienstig of humanistisch onderwijs te volgen. In België is dit zelfs grondwettelijk vastgelegd: conform art. 24, \1 zijn officiële scholen er immers verplicht om onderwijs in de erkende erediensten en in de niet-confessionele zedenleer aan te bieden. Dit betekent dat leerlingen momenteel kunnen kiezen tussen rooms-katholieke, protestantse, orthodox-christelijke en anglicaanse godsdienst ${ }^{8}$, jodendom, islam, en niet-confessionele zedenleer. ${ }^{10}$ Ook in Nederland bestaat de mogelijkheid om levensbeschouwelijk onderwijs te volgen op de openbare school, waar ouders (of leerlingen) kunnen vragen om boeddhistisch, hindoeïstisch, humanistisch, islamitisch, joods, protestants of katholiek vormingsonderwijs. Anders dan in België is deze regulering niet grondwettelijk vastgelegd. Wat beide landen wel gemeen hebben is dat niet de overheid, maar de betreffende (erkende) levensbeschouwelijke instanties verantwoordelijk zijn voor de leerplannen, handboeken en inspectie, en voor de opleiding en benoeming van onderwijsgevenden. Het levensbeschouwelijk onderwijs wordt er dus op een denominationele - en hierdoor doorgaans ook op een confessionele - manier georganiseerd. ${ }^{11}$

\section{Religieonderwijs in Europa: een vergelijkend perspectief}

Onder invloed van de secularisering en toenemende levensbeschouwelijke diversiteit is het hierboven geschetste religieonderwijs de laatste decennia sterk geseculariseerd en gepluraliseerd: naast het van oudsher katholiek en in 
Nederland ook protestants-christelijk en gereformeerd godsdienstonderwijs is er steeds meer ruimte gekomen voor onderwijs in andere (door de overheid erkende) religies en/of in het (vrijzinnig) humanisme. In België komt dit pluralisme vooral tot uiting op de officiële scholen, waar ouders/leerlingen verondersteld worden een keuze te maken uit zeven levensbeschouwelijke vakken. ${ }^{12}$ In Nederland is dit pluralisme vooral zichtbaar in het bijzonder onderwijs, waar het aanbod van bijzondere scholen gevarieerder is dan in België. Ondanks deze verschillen valt het op dat het religieonderwijs in beide landen principieel nog steeds door de levensbeschouwelijke instanties en/of scholen, en niet door de overheid, wordt georganiseerd. Bovendien lijkt de focus vooral te liggen op socialisatie in de eigen levensbeschouwing en dus op onderwijs in en vanuit één specifieke levensbeschouwelijke traditie.

Het kan echter ook anders. Zo is het godsdienstonderwijs sinds de jaren zeventig van de vorige eeuw in een aantal Scandinavische landen en in het Verenigd Koninkrijk geseculariseerd: niet de kerk(en), maar de overheid richt dit onderwijs in, stelt de leerplannen op, controleert hand- en werkboeken, voert de inspectie uit, en zorgt voor de opleiding en benoeming van lesgevers. Bovendien is het primaire doel van dit religieonderwijs, dat men in deze landen overigens zowel in openbare als in door de overheid gesubsidieerde bijzondere scholen terug kan vinden ${ }^{13}$, niet langer de socialisatie van een groep gelovigen in één specifieke levensbeschouwing, maar het verwerven van algemene basiskennis over religie ('levensbeschouwelijke geletterdheid'). Hiertoe worden religies niet (langer) vanuit een binnenperspectief, maar vanuit een buitenperspectief benaderd en worden leerkrachten niet langer opgeleid in de theologie, maar in de academische studie van de religie of de 'religiewetenschap' (cf. Alberts 2019; Jensen 2019; Kjeldsen 2019).

Tot slot zijn er ook een aantal landen waarin religie/levensbeschouwing niet (langer) als apart vak op het curriculum staat. Het meest gekende voorbeeld is Frankrijk, dat conform het principe van de laïcité sinds 1905 geen levensbeschouwelijk onderwijs aanbiedt in het openbaar onderwijs. ${ }^{14}$ Sinds 2017 vaart Luxemburg een vergelijkbare koers: in dat jaar werden de vakken 'rooms-katholieke godsdienst' en 'morele opvoeding' in het openbaar onderwijs vervangen door een vak 'Vie et Société', waarin ook ruimte is voor diverse levensbeschouwingen en hun betekenis voor en impact op de samenleving (cf. Braem 2018). Ook in de gesubsidieerde bijzondere scholen die de leerprogramma's van de openbare scholen volgen, staat dit vak op het curriculum. ${ }^{15}$ 
Wanneer we deze verschillende modellen in vergelijkend perspectief plaatsen, zien we een opvallend patroon terugkeren: in landen met een katholieke of gemengde (katholieke + protestantse) levensbeschouwelijke achtergrond (met uitzondering van Frankrijk en Luxemburg) wordt religieonderwijs op de openbare school nog steeds autonoom georganiseerd door de katholieke (en in gemengde landen ook protestantse) kerk(en) en wordt het doorgaans op een confessionele manier georganiseerd: het gaat, in de woorden van de godsdienstpedagoog Michael Grimmitt (1987), om education into religion en niet om education about religion. In landen met een lutherse en anglicaanse achtergrond zien we een ander verhaal: daar wordt het godsdienstonderwijs niet langer door de (Lutherse of Anglicaanse) Kerk, maar door de overheid georganiseerd en gaat het niet langer om onderwijs in een bepaalde religie, maar om onderwijs over diverse levensbeschouwingen. ${ }^{16}$

Tot slot zien we in een aantal landen (bv. Nederland en Zwitserland) dat onderwijs in en over levensbeschouwingen naast elkaar worden aangeboden. Zo zijn alle Nederlandse basisscholen - bijzonder en openbaar - sinds 1985 wettelijk verplicht om leerlingen op een neutrale en objectieve manier te informeren over de belangrijkste geestelijke stromingen in Nederland. Dit kan in principe via een apart vak 'geestelijke stromingen', maar gewoonlijk kiezen scholen ervoor om de kennisbasis geestelijke stromingen te integreren in andere vakken (cf. infra). Ook in een aantal Zwitserse kantons worden onderwijs in en over religie gecombineerd: naast het (vrij recent ingevoerde) verplicht onderwijs over levensbeschouwingen kunnen leerlingen op de openbare school er kiezen om (extra-curriculair) onderwijs in religie (voornamelijk calvinisme en katholicisme) te volgen. De kaart hieronder (figuur 1) biedt een overzicht van de levensbeschouwelijke achtergrond en het aangeboden religieonderwijs op de openbare scholen in Noord-, Centraal- en Zuid-Europa. ${ }^{17}$ 
Figuur 1. Levensbeschouwelijke achtergrond en religieonderwijs op openbare scholen in Europa ${ }^{18}$

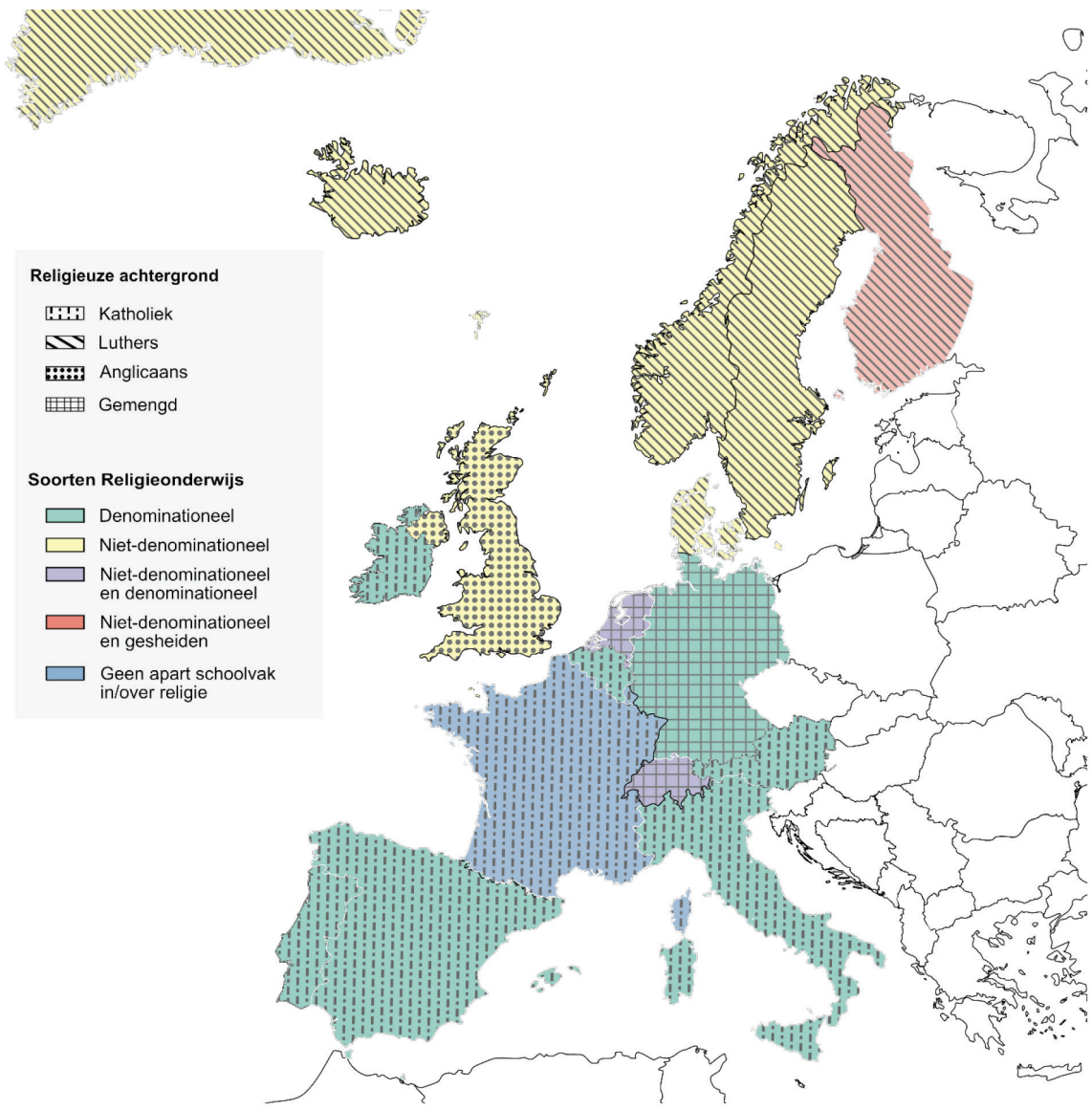

\section{Kerk, staat en religieonderwijs: drie modellen, drie patronen}

Voor de hierboven geschetste evoluties in het religieonderwijs op de openbare scholen zijn er een aantal verklaringen mogelijk. Zo is de Lutherse Kerk (en wat volgt geldt eveneens voor de Anglicaanse Kerk) theologisch gezien in het verleden erg ontvankelijk geweest voor bijbelhermeneutiek en godsdienstfenomenologie, wat minder vanzelfsprekend was binnen de Katholieke Kerk. Zowel bijbelhermeneutiek als godsdienstfenomenologie hebben op hun beurt een grote impact gehad op het ontstaan van de academische discipline van de religiewetenschap en het daarop gebaseerde religieonderwijs. Niet toe- 
vallig waren de pioniers van de vergelijkende religiewetenschap (bv. Van der Leeuw, Kristensen en Smart) geen katholieken, maar (liberale) protestanten die soelaas zagen in een objectief-wetenschappelijke studie van het fenomeen 'religie'. Daarnaast wijzen we, met de Deense kerkhistorica Mette Buchardt (2015), op het belang van het culturele protestantisme en de link ervan met de welvaartsstaat en met uniform, door de overheid georganiseerd religieonderwijs. Tot slot is ook de specifieke kerk-staat verhouding een belangrijke factor (geweest) in de evolutie en organisatie van het religieonderwijs. In wat volgt zal ik mij op deze laatste verklaring focussen. Hiertoe zal ik kort drie kerkstaat regimes en hun impact op het religieonderwijs bespreken. Deze zijn: (1) staatskerk; (2) wederzijdse onafhankelijkheid; en (3) strikte scheiding tussen kerk en staat.

\subsection{Staatskerk: van denominationeel en mono-confessioneel naar niet- denominationeel en niet-confessioneel religieonderwijs}

In landen met een staatskerk of established church zijn er nauwe officiële banden tussen kerk en staat en heeft de staatskerk diverse (maatschappelijke en financiële) privileges, onder meer op het gebied van (religie)onderwijs. Zo is de staat in de Scandinavische landen bevoegd voor onderwijs, maar omdat kerk en staat er zeer nauw op mekaar betrokken zijn, was religieonderwijs op openbare scholen van oudsher van lutherse strekking. Hierbij was de Lutherse Kerk, als overheidsactor, verantwoordelijk voor de organisatie en controle van de godsdienstlessen. ${ }^{19}$

Tot het midden van de twintigste eeuw identificeerde een substantiële meerderheid van de Scandinavische bevolking zich met de Lutherse Kerk en was er niet meteen behoefte aan een vrijstellingsregeling voor het religieonderwijs en/of aan de organisatie van één of meerdere alternatieve vakken. Door de toenemende secularisering en levensbeschouwelijke diversiteit kon dit mono-confessionele model echter niet langer standhouden: in 1969 startte Zweden officieel met niet-confessioneel religieonderwijs, in 1975 volgde Denemarken en in 1997 werd ook het religieonderwijs in Noorwegen officieel gedeconfessionaliseerd. Opvallend is dat er bij deze wijzigingen in het religieonderwijs geen wijzigingen in de kerk-staat verhoudingen nodig waren ${ }^{2 \circ}$ : in het mono-confessionele model was de Lutherse Kerk immers als overheidsactor verantwoordelijk voor het religieonderwijs op de openbare school en met de overheveling van deze verantwoordelijkheid naar het Ministerie van Onderwijs, dat eveneens als overheidsactor fungeert, is er op het institutionele gebied principieel niet veel gewijzigd. 
Overigens blijkt de Lutherse Kerk, zowel voor als na de 'shift' nog steeds een zekere greep te hebben op het religieonderwijs dat op het nationale curriculum staat. Zo stelt Jenny Berglund (2013) dat het religieonderwijs in Zweden 'gemarineerd is in luthers protestantisme' en ook in Noorwegen en Denemarken heeft de Lutherse Kerk een niet te onderschatten invloed op de inhoud en methodologie van het religieonderwijs (voor Noorwegen: zie bv. Andreassen 2013; voor Denemarken: zie bv. Buchardt 2014). Het inhoudelijk (en dus niet enkel formeel) loskoppelen van het lutherse geloof en het religieonderwijs blijkt dus geen sinecure en vormt één van de grootste uitdagingen voor het religieonderwijs in de genoemde landen.

\subsection{Wederzijdse onafhankelijkheid: van denominationeel en mono- confessioneel naar denominationeel en pluralistisch religieonderwijs}

Terwijl het Noorden van Europa een overwegend lutherse achtergrond heeft, hebben de meeste landen in Centraal- en Zuid-Europa van oudsher een katholieke of gemengde (katholieke + lutherse/calvinistische) achtergrond. Hoewel de Rooms-katholieke Kerk er nog steeds een machtig instituut is - in het bijzonder op het gebied van onderwijs, ethiek en politiek - is ze er geen staatskerk (meer). Wel werden er in het verleden concordaten gesloten met de Heilige Stoel in Rome, wat heeft geleid tot een (in sommige landen grondwettelijk vastgelegd) beleid van 'welwillende neutraliteit' en 'wederzijdse onafhankelijkheid' tussen kerk en staat.

Dit institutionele systeem impliceert onder meer dat kerk en staat gescheiden, autonome actoren zijn: het komt niet toe aan de overheid om zich in te laten met religie, maar ook omgedraaid hoeven religies zich niet bezig te houden met staatszaken en politiek. Dit betekent echter niet dat interactie en samenwerking tussen beide instituties onmogelijk zouden zijn: immers, om de godsdienstvrijheid niet enkel op een passieve maar ook op een actieve manier te garanderen, kan de staat ervoor kiezen om religies actief te ondersteunen. Dit kan onder meer via verplichte of vrijwillige kerkbelastingen; overheidssteun voor confessionele scholen en andere instellingen die een levensbeschouwelijke grondslag hebben (denk hierbij aan de vele zorginstellingen met een levensbeschouwelijke grondslag in België en in Nederland); subsidies voor aalmoezeniers; en de organisatie en financiering van religieonderwijs in openbare en bijzondere scholen.

Wat dat laatste betreft, benadrukt de Rooms-katholieke Kerk, in een omzendbrief van de Congregatie voor Katholiek Onderwijs uit 2009, het belang van godsdienstonderwijs 
... in the more general milieu of school, whether it be Catholic or State-run. The families of believers have the right to such education; they must have the guarantee that the State school - precisely because it is open to all - not only will not put their children's faith in peril, but will rather complete their integral formation with appropriate religious education.

Volgens de Congregatie is 'gepast religieonderwijs' geen 'neutraal' religieonderwijs dat gebaseerd is op de academische studie van de religie (religiewetenschap), want dit soort onderwijs zou leiden tot "verwarring" en tot "relativisme of onverschilligheid". Gepast religieonderwijs, aldus de Congregatie, "behelst kennis over de identiteit van het Christendom en het christelijke leven" en is verrijkend voor zowel de kerk als de mensheid (Congregation for Catholic Education 2009). Om dit soort religieonderwijs te realiseren, is er nood aan een wederzijdse samenwerking tussen kerk en staat: terwijl de overheid religieonderwijs in openbare scholen faciliteert (bv. door ruimte te creëren in het curriculum, door in de nodige infrastructuur te voorzien en door lesgevers te bezoldigen), komt het aan de kerk (i.e. de lokale bisschoppen) toe om voor de inhoud en controle van het godsdienstonderwijs te zorgen:

Government therefore ought indeed to take account of the religious life of the citizenry and show it [a] favor, since the function of government is to make provision for the common welfare. However, it would clearly transgress the limits set to its power, were it to presume to command or inhibit acts that are religious. (Congregation for Catholic Education 2009)

Volgens de Congregatie komt het aan de Rooms-katholieke Kerk - en niet aan de staat - toe om de inhoud van het godsdienstonderwijs te bepalen: enkel op die manier kan het godsdienstonderwijs daadwerkelijk katholiek en authentiek zijn. Deze religieuze autonomie op het gebied van godsdienstonderwijs is één van de redenen waarom een overgang van denominationeel naar niet-denominationeel religieonderwijs niet evident was (en nog steeds niet evident is) in katholieke en gemengde landen. Anders dan in de landen met een lutherse achtergrond was de Rooms-katholieke Kerk sinds haar disestablishment als staatskerk, niet langer een officiële overheidsactor, maar een onafhankelijke partner van de staat. Vanuit dit institutioneel perspectief is het eenvoudiger deze autonomie te behouden en te kiezen voor gepluraliseerd, maar nog steeds denominationeel religieonderwijs, dan deze autonomie op 
te geven en de overgang te maken naar een niet-denominationeel (en nietconfessioneel) model.

Kortom, hoewel de overgang van mono-confessioneel naar pluriform religieonderwijs op theologisch en inhoudelijk gebied niet altijd evident was, was er voor deze verandering geen substantiële wijziging nodig op het gebied van kerk-staat verhoudingen en, hiermee samenhangend, op het gebied van de organisatie en controle van het religieonderwijs: in het mono-confessionele model was de kerk (katholiek en/of protestants) als autonome en onafhankelijke actor verantwoordelijk voor het religieonderwijs en dit alles is principieel hetzelfde gebleven in een pluriform model, waarin verschillende (erkende) religies en levensbeschouwingen verantwoordelijk zijn voor de organisatie, inhoud en inspectie van de betreffende religievakken. Op institutioneel gebied past het pluriforme model dus mooi binnen het kerk-staat model van 'wederzijdse onafhankelijkheid' en een substantiële wijziging in dit kerk-staat model was niet nodig om in te kunnen zetten op pluriform religieonderwijs.

\subsection{Strikte scheiding: van denominationeel en confessioneel religieonderwijs naar burgerschap en filosofie}

Een derde, en eerder uitzonderlijk kerk-staat model vinden we terug in Frankrijk, waar kerk en staat sinds 1905 strikt gescheiden zijn. Dit betekent onder meer dat religieuze gemeenschappen en organisaties niet direct worden gefinancierd door de overheid; dat ambtenaren en leerlingen in de openbare school geen 'opvallende' religieuze kentekens mogen dragen; en dat er geen ruimte is voor religieonderwijs in de openbare school. ${ }^{21}$

Eén van de basisprincipes in het Franse onderwijsbeleid is dat onderwijs een aangelegenheid is van de staat ${ }^{22}$ en bijdraagt aan de vorming van Franse, republikeinse burgers. Om dit mogelijk te maken wordt er veel belang gehecht aan de vakken 'burgerschap' en 'filosofie': vakken die strikt gescheiden zijn van het religieonderwijs en waarin leerlingen worden uitgenodigd kritisch na te denken over hun (toekomstige) rol als democratische burgers (cf. Van den Kerckhove 2011; Willaime 2014; Gaudin 2017). Sinds 2004 wordt onderwijs over religieuze feiten (le fait religieux) geïntegreerd in vakken zoals aardrijkskunde, geschiedenis en literatuur, maar het wordt in de Franse openbare scholen niet aangeboden als een apart schoolvak.

Volgens de zogenaamde 'seperationists' (cf. Franken 2016, Ch. 12) is dit beleid het meest 'neutrale' beleid dat mogelijk is in een liberale democratie: wanneer religieonderwijs naar de privésfeer wordt verbannen, kan de scheiding tussen kerk en staat, en hiermee ook de neutraliteit van de overheid, gevrijwaard worden. Immers, de staat (Ministerie van Onderwijs) hoeft in 
het Franse model niet te bepalen welke religievakken al dan niet aangeboden kunnen worden op school; hoe en waar godsdienstleerkrachten opgeleid moeten worden; hoe de vakken er inhoudelijk moeten uitzien; etc. Dit soort zaken, die meer dan eens leiden tot spanningen tussen kerk en staat en tot het overschrijden van hun respectievelijke grenzen, zijn simpelweg niet aan de orde wanneer er geen godsdienstonderwijs op het curriculum van de openbare school staat. Volgens deze logica hoort trouwens ook een door de overheid georganiseerd vak over religies en levensbeschouwingen niet thuis op het curriculum omdat ook de organisatie hiervan zou kunnen leiden tot een aantasting van de scheiding tussen kerk en staat.

Anders dan de meeste katholieke en gemengde landen heeft Frankrijk dus niet gekozen voor een pluralistisch model van religieonderwijs (met uitzondering van de regio Alsace-Moselle), maar voor een model waarin religieonderwijs niet langer op het curriculum van de openbare school staat. In 2017 heeft ook Luxemburg dit model ingevoerd: na een periode van mono-confessioneel katholiek godsdienstonderwijs werd er gekozen voor een minimaal pluralistisch model waarin er naast katholieke godsdienst ook morele opvoeding werd aangeboden. Vervolgens werden beide vakken vervangen door een algemeen vormend vak Vie et Société, waarin onder meer aandacht is voor een basiskennis levensbeschouwelijke geletterdheid (Braem 2018). Net zoals in Frankrijk in 1905 maakt deze wijziging deel uit van een bredere institutionele verandering, waarbij kerk en staat ook op andere domeinen van mekaar gescheiden zullen worden.

\section{Religieonderwijs in België en Nederland: naar een pragmatische aanpak?}

De verschillende kerk-staat modellen en hun implicaties voor de organisatie van het religieonderwijs kunnen voor een groot deel verklaren waarom dat religieonderwijs in de tweede helft van de twintigste eeuw voornamelijk gedeconfessionaliseerd is in lutherse en anglicaanse landen, maar niet in katholieke en gemengde landen. Aan het begin van de eenentwintigste eeuw zien we echter dat dit patroon op sommige plaatsen (licht) lijkt te wijzigen. Zo is het religieonderwijs in verscheidene kantons in Zwitserland (een gemengd land met een kerk-staat model dat er afhankelijk van het betreffende kanton één kan zijn van strikte scheiding [bv. in Genève] of van wederzijdse onafhankelijkheid) het voorbije decennium sterk gedeconfessionaliseerd en is confessioneel religieonderwijs er niet langer de norm (cf. Rota 2015). 
Ook in Luxemburg (katholiek) zien we hoe het confessioneel religieonderwijs plaats heeft gemaakt voor niet-confessioneel religieonderwijs. Deze wijzigingen gingen echter niet over een nacht ijs omdat hiertoe vaak institutionele aanpassingen op het gebied van kerk en staat noodzakelijk waren. Omdat het verre van evident is dit soort institutionele aanpassingen door te voeren, zijn verregaande wijzigingen in het religieonderwijs voorlopig in de meeste katholieke en gemengde landen tot nog toe uitgebleven. Wel zien we dat een aantal landen, waaronder België en Nederland, in de praktijk lijken te evolueren naar een vorm van gedeconfessionaliseerd religieonderwijs, zonder echter aan de institutionele inbedding van dit onderwijs (en aan de hiermee samenhangende kerk-staat verhoudingen) te raken. In wat volgt bespreek ik drie manieren waarop dit momenteel gebeurt in deze landen.

\subsection{Niet-confessioneel en denominationeel}

De laatste decennia is er in het vak 'katholieke godsdienst' in België (maar ook in heel wat andere landen) meer openheid gekomen voor anders- en nietgelovigen en hun tradities en is het geëvolueerd naar wat ik elders (Franken 2017) 'semi-confessioneel religieonderwijs' heb genoemd. Hoewel in de praktijk veel afhangt van de lesgever, zou men het vak rooms-katholieke godsdienst op dit moment kunnen omschrijven als een open en pluralistisch vak, waarin zowel dialoog tussen verschillende religies/levensbeschouwingen als ook kennismaking met het christendom, centraal staan. Deze dialoog en openheid vertrekken wel steeds vanuit een binnenperspectief en meer bepaald vanuit de rooms-katholieke traditie, die een voorkeurspositie bekleedt van waaruit andere levensbeschouwingen worden bestudeerd. Zo lezen we in de officiële verklaring voor het katholiek godsdienstonderwijs in Vlaanderen dat

[d]e leerplannen r.-k. godsdienst [...] moeten voldoen aan een dubbele opdracht: het bijbrengen van zowel religieuze geletterdheid als (inter)levensbeschouwelijke vaardigheden, vanuit een rooms-katholiek perspectief. [...] Omdat godsdienst en levensbeschouwing te maken hebben met wat mensen ten diepste raakt en met persoonlijke keuzes, kan men ze alleen van binnenuit leren kennen. [...] Alleen vanuit een binnenperspectiefkan men de betekenis van een levensbeschouwing of godsdienst ten volle leren kennen en waarderen. (De Vlaamse Bisschoppen \& de Erkende Instantie Rooms-katholieke godsdienst 2017)

Door het toenemend aantal niet-katholieke leerlingen in het katholiek onderwijs is er de laatste decennia in het vak rooms-katholieke godsdienst in Vlaanderen (en dat geldt ook voor de Franse en Duitse Gemeenschap) steeds 
meer openheid gekomen voor 'andere' levensbeschouwingen en voor interlevensbeschouwelijke dialoog. ${ }^{23}$ Conform de onder punt 4.2 aangehaalde visietekst van de Congregatie voor de Geloofsleer en de nog steeds geldende visietekst van de Belgische bisschoppen uit $1996^{24}$, is het vak principieel nog steeds een vak waarin de eigen traditie een voorkeurspositie heeft. Daarom zou men dit soort religieonderwijs als 'semi-confessioneel' kunnen omschrijven.

Een fundamentelere wijziging vinden we terug in Nederland, waar het religieonderwijs in een aantal scholen is geëvolueerd tot wat men 'nietconfessioneel, denominationeel' religieonderwijs zou kunnen noemen. Gezien het hoge aantal scholen met confessionele (katholieke en protestantse) grondslag enerzijds en de hoge seculariseringsgraad onder jongeren anderzijds, lopen heel wat niet-gelovige jongeren school in katholieke en protestantschristelijke scholen (cf. Van Dijk-Groeneboer 2017). Officieel dragen deze scholen nog het label 'katholiek' of 'protestants-christelijk', maar in de praktijk zijn ze de laatste decennia sterk geseculariseerd. Dit heeft zich onder meer vertaald in het godsdienstonderwijs op katholieke scholen: wat er eerst 'godsdienstonderwijs' werd genoemd, heeft plaatsgemaakt voor wat nu 'levensbeschouwelijke vorming' of kortweg 'levensbeschouwing' heet. Het primaire doel van dit onderwijs is niet langer het socialiseren van de leerlingen in één specifieke religieuze traditie, maar de ontwikkeling van een persoonlijke levensbeschouwing. Op die manier heeft het levensbeschouwelijk onderwijs op katholieke scholen zich als het ware gedeconfessionaliseerd en zich ontwikkeld tot 'seculier' onderwijs met de nadruk op levensbeschouwelijke identiteitsvorming (cf. Alii 2009, 117; Vermeer \& Franken 2018, 303-304).

Niettegenstaande deze deconfessionalisering in de praktijk, wordt het religieonderwijs op het institutionele niveau nog steeds op een denominationele manier georganiseerd: niet de overheid, maar de kerk(en) en/of confessionele scholen staan officieel in voor de inhoud en organisatie. Kortom, inhoudelijk is het religieonderwijs op heel wat scholen in Nederland en België geëvolueerd, zonder dat het verzuilde model en het kerk-staat model van wederzijdse onafhankelijkheid werden gewijzigd.

\subsection{Kerncurriculum levensbeschouwing}

Een andere, en in Nederland parallelle manier om het religieonderwijs te deconfessionaliseren, is de implementatie van een kerncurriculum levensbeschouwing. Om leerlingen een zekere 'levensbeschouwelijke geletterdheid' bij te brengen en hopende op die manier wederzijds respect, dialoog en tolerantie te kunnen stimuleren, heeft het Ministerie van Onderwijs in 
1985 een kerncurriculum geestelijke stromingen opgesteld voor het basisonderwijs. Grosso modo ligt de focus hiervan op de 5 grote 'wereldreligies' en het seculiere humanisme en worden deze 'geestelijke stromingen' behandeld vanuit de verschillende religieuze dimensies van Ninian Smart. Het kerncurriculum wordt voornamelijk geïntegreerd in reeds bestaande schoolvakken (zoals in het Franse model), maar scholen kunnen er ook voor kiezen om een apart - confessioneel of niet-confessioneel - religievak te organiseren waarin de doelstellingen en inhouden van het kerncurriculum worden geïntegreerd. Conform de vrijheid van onderwijs zijn scholen vrij te kiezen welke strategie ze volgen.

Ook secundaire scholen zijn verplicht leerlingen inzicht te verschaffen in cultuur en levensbeschouwing en in diverse levensbeschouwelijke stromingen (cf. Kerndoel 43) ${ }^{25}$, maar uit onderzoek blijkt dat deze thema's slechts sporadisch aan bod komen in vakken als maatschappijleer, geschiedenis of aardrijkskunde (Beemsterboer 2011). Om deze lacune op te vullen en omdat degelijk religieonderwijs vandaag de dag onontbeerlijk is om de hedendaagse samenleving te begrijpen, riepen een aantal religiewetenschappers in 2016 via de media op om een verplicht vak 'religiewetenschap' in alle secundaire scholen in te richten. Hiertoe ontwikkelden ze, samen met een aantal stakeholders en academici, een rationale voor een kerncurriculum levensbeschouwing (Davidsen et al. 2017). Momenteel wordt er, in opdracht van een brede alliantie van partners uit het veld ${ }^{26}$, door het expertisecentrum LERVO (Levensbeschouwing en religie in het voortgezet onderwijs) gewerkt aan de concrete uitwerking van een 'Basiscurriculum Levensbeschouwing en Religie' voor heel het voortgezet onderwijs (bijzonder en openbaar). Een eerste aanzet voor zo een curriculum is terug te vinden in Narthex (Davidsen 2020) en zal, na diverse consultatierondes met onder meer docenten en opleiders, in de loop van 2021 verder ontwikkeld worden. Als de implementatie van dit curriculum er ooit zou komen, zou dit opnieuw een voorbeeld kunnen zijn van hoe het religieonderwijs gedeconfessionaliseerd wordt, zonder verregaande institutionele wijzigingen: terwijl het verzuilde onderwijssysteem behouden blijft en religieuze stakeholders officieel verantwoordelijk blijven voor het religieonderwijs, wordt er gezorgd voor de organisatie en implementatie van een kerncurriculum 'levensbeschouwing' dat alle scholen, wat hun levensbeschouwelijke grondslag ook moge zijn, dienen te volgen.

\subsection{Creatieve omgang met de (grond)wet}

In een aantal landen (waaronder België) maakt de organisatie van het religieonderwijs deel uit van de grondwet. Hierdoor is het erg moeilijk om op korte 
termijn grondige wijzigingen door te voeren op institutioneel niveau. Wel kan men, als alternatief, de (grond)wet herinterpreteren opdat het religieonderwijs beter is aangepast aan de hedendaagse tendensen van secularisering en diversiteit. Zo vereist artikel 24, \1 van de Belgische grondwet dat officiële scholen “... tot het einde van de leerplicht, de keuze aan[bieden] tussen onderricht in een der erkende godsdiensten en de niet-confessionele zedenleer". De derde paragraaf voegt daar aan toe dat "alle leerlingen die leerplichtig zijn, ten laste van de gemeenschap recht op een morele of religieuze opvoeding [hebben]", wat betekent dat ook in het vrije onderwijs de godsdienstlessen door de overheid worden gefinancierd.

Volgens Lievens $(2019,128)$ is het onduidelijk of het grondwettelijk verplicht is om deze lessen levensbeschouwing binnen het reguliere curriculum te organiseren. In 1993 was dit sowieso niet langer het geval: in dat jaar werd het vrijzinnig humanisme immers officieel als levensbeschouwing erkend, wat betekende dat vanaf dat jaar ook deze levensbeschouwing het recht had op een eigen vak in het officieel onderwijs. In Vlaanderen werd de bevoegdheid voor het vak niet-confessionele zedenleer daarom overgeheveld van de staat naar wat nu de Raad voor Inspectie \& Kwaliteitszorg niet-confessionele Zedenleer heet. ${ }^{27}$ Hierdoor was een 'neutraal' alternatief voor leerlingen die zich in geen enkele van de aangeboden vakken (inclusief het humanistische vak niet-confessionele zedenleer) konden vinden niet langer gegarandeerd en werd er een vrijstellingsregel in het leven geroepen. De facto betekende dit dat de godsdienstlessen in het officieel onderwijs strikt genomen geen reguliere vakken meer waren. Immers, wie dat wenste, kon op eenvoudig verzoek vrijgesteld worden. Van hieruit lijkt het slechts een kleine stap om religieonderwijs niet langer op het reguliere curriculum te plaatsen, maar om het als extra-curriculair, optioneel vak aan te bieden.

Dit is overigens sinds zeer kort de officiële regulering voor 5-jarige kleuters in het Vlaams onderwijs: sinds de leerplicht in België op federaal niveau verlaagd werd van 6 jaar (eerste jaar basisonderwijs) naar 5 jaar (laatste jaar kleuteronderwijs), hebben 5-jarige kleuters in het officieel onderwijs met ingang van september 2020 ook recht op onderwijs in de erkende levensbeschouwingen. ${ }^{28}$ Om hieraan tegemoet te komen heeft de Vlaamse Regering gekozen voor een opt-in beleid en dus niet langer voor een opt-out beleid: religieonderwijs wordt voor kleuters niet aangeboden als een regulier schoolvak in het curriculum, maar als ouders dat wensen, kunnen hun kinderen onderwijs in één van de erkende levensbeschouwingen volgen. Hiertoe sluiten ze aan bij de leerlingen van het eerste leerjaar. Als dit systeem de grondwettelijke toets doorstaat, zou het een mogelijke opstap kunnen zijn naar bredere hervormin- 
gen, zoals de invoering van een algemeen vormend vak levensbeschouwing, ethiek, filosofie (LEF) ${ }^{29}$, dat de huidige religievakken zou kunnen vervangen. Deze vakken zouden dan, net zoals in het laatste jaar van het kleuteronderwijs, optioneel kunnen worden aangeboden bovenop het curriculum. Dit ligt in het verlengde van een voorstel dat werd opgenomen in het regeerakkoord van Brussel en Wallonië (2019-2024) en naar alle waarschijnlijkheid verder onderzocht zal worden onder de huidige legislatuur:

Lécole doit être un lieu de vie et d'activité, ouvert et participatif. Le Gouvernement s'engage à : Charger un groupe de travail spécifique au sein du Parlement de la Fédération Wallonie-Bruxelles d'examiner l'extension à deux heures de l'éducation à la philosophie et à la citoyenneté pour l'ensemble des élèves de l'enseignement obligatoire. (Déclaration de politique Fédération Wallonie Bruxelles, 16; mijn cursivering) ${ }^{30}$

Een andere mogelijkheid die binnen de constitutionele grenzen valt, is een reductie van het aantal uren godsdienst/zedenleer. Zo heeft de Franse Gemeenschap, in de nasleep van een rechtszaak rond vrijstelling in $2015^{31}$, besloten om het aantal uren godsdienst/zedenleer in het officieel onderwijs te halveren (van 2 uur per week naar 1 uur per week). Zodoende kon er in het vrijgekomen uur een nieuw, verplicht vak Cours de Philosophie et de Citoyenneté $(C P C)$ worden ingericht. Deze wijziging, die eveneens gezien kan worden als een (gedeeltelijke) deconfessionalisering binnen het bestaande constitutionele kader, werd gedeeltelijk opgenomen in het Vlaams Regeerakkoord (20192024):

In de derde graad van het secundair onderwijs kan het gemeenschapsonderwijs overschakelen van $2 u$ levensbeschouwing naar $1 \mathrm{u}$ levensbeschouwing en $1 \mathrm{u}$ interlevensbeschouwelijke dialoog, waarbinnen eveneens (vakoverschrijdende) eindtermen die passen binnen burgerschap worden gerealiseerd..$^{2}$

\section{Pragmatische wijzigingen: een evaluatie}

Eén van de voordelen van de hierboven geschetste wijzigingen is dat het religieonderwijs in de praktijk kan worden aangepast in functie van het gewijzigde levensbeschouwelijke landschap, zonder dat er verregaande - en vaak langzame - institutionele en/of grondwettelijk wijzigingen nodig zijn. Wel zijn er een aantal risico's verbonden aan deze pragmatische aanpak, waar men rekening mee dient te houden. 
Zo kunnen er bij behoud van denominationeel religieonderwijs problemen zijn met de inhoud, het lesmateriaal, de lerarenopleiding en de inspectie. Conform de scheiding van kerk en staat is het als overheid niet toegelaten om de inhoud en kwaliteit van dit soort religieonderwijs te controleren. Dit kan er toe leiden dat er in de praktijk grote inhoudelijke en kwalitatieve verschillen zijn: terwijl sommige leerkrachten op een zeer open manier les zullen geven en zowel kennis van diverse levensbeschouwelijke tradities alsook kritische reflectie en dialoog zullen stimuleren, is het mogelijk dat andere leerkrachten dat niet doen en opteren voor een gesloten, eerder catechetische aanpak. Zolang de (erkende) levensbeschouwingen hiermee instemmen, is er niets aan de hand.

Deze onmogelijkheid om als overheid het religieonderwijs te controleren kan bovendien tot een spanning leiden tussen het religieonderwijs enerzijds, en andere - seculiere - schoolvakken anderzijds. Zo werd in Nederland in 2005 wettelijk vastgelegd dat alle scholen (bijzonder en openbaar) moeten werken aan de integratie van leerlingen in de Nederlandse samenleving. Hiertoe wordt voorlopig geen apart schoolvak 'burgerschap' georganiseerd, maar de kerndoelen worden geïntegreerd in reeds bestaande vakken, waartoe ook de religievakken kunnen behoren. Het is echter een groot vraagteken of het überhaupt wel mogelijk is om dat te doen, zonder aan de scheiding tussen kerk en staat te raken: heeft het wel zin om als overheid de kerndoelen burgerschap vast te leggen, terwijl deze vervolgens kunnen worden geïntegreerd in een vak dat principieel niet door de overheid gecontroleerd mag worden?33

Ook in Vlaanderen is de combinatie van religieonderwijs en burgerschapseducatie een heikel punt. Conform het hierboven geciteerde regeerakkoord kan het Gemeenschapsonderwijs ${ }^{34}$ immers van 2 uur levensbeschouwing overgaan naar 1 uur levensbeschouwing en 1 uur interlevensbeschouwelijke dialoog, waarbinnen eveneens (vakoverschrijdende) eindtermen burgerschap kunnen worden gerealiseerd. Al vrij snel na de publicatie van het Regeerakkoord gaven de afgevaardigden van de erkende levensbeschouwingen, in een gezamenlijke verklaring, aan om in overleg met het Gemeenschapsonderwijs, "ten volle onze verantwoordelijkheid te nemen daar waar men voor de mogelijkheid kiest het tweede uur anders in te vullen." 35 Niet alleen getuigt dit voorstel van een erg defensieve houding, het is ook maar de vraag of dit voorstel realistisch is wanneer de verantwoordelijkheid voor de levensbeschouwelijke vakken bij de erkende instanties - en niet bij de overheid - blijft liggen.

Wanneer we rekening houden met deze opmerkingen, lijkt het misschien meer aangewezen om te opteren voor een door de overheid goedgekeurd kerncurriculum levensbeschouwing. Maar ook hier duiken er een aantal 
problemen op. Immers, in een verzuild onderwijsstelsel zoals we dat kennen in België en Nederland is het niet ondenkbaar dat een aantal onderwijsverstrekkers niet gediend is met een dergelijk kerncurriculum. Hoe ver reikt de autonomie van deze onderwijsverstrekkers en wat moet er gebeuren wanneer de godsdienst- en onderwijsvrijheid botsen met de onderwijs- en ontwikkelingsdoelstellingen die de overheid voorschrijft? Is het daadwerkelijk mogelijk om iedereen een basis levensbeschouwelijke geletterdheid bij te brengen zonder aan een aantal grondwettelijke principes, die aan de basis liggen van ons verzuilde landschap, te raken? Of zijn diepgaandere institutionele wijzigingen in dit geval onvermijdelijk?

Tot slot is er ook een limiet aan wat ik hierboven constitutionele creativiteit heb genoemd. Zoals blijkt uit de geschetste voorbeelden, is er een belangrijk verschil tussen de letter en de geest van de wet, waardoor sommige veranderingen niet stroken met de oorspronkelijke intentie van de wet. Dat is echter niet zonder risico: tot op vandaag heeft de organisatie van religieonderwijs in verschillende landen wereldwijd al tot diverse rechtszaken geleid en het is niet gegarandeerd dat rechters altijd zullen instemmen met een hernieuwde interpretatie van de wet. Bovendien biedt niet elke (grond)wet evenveel speelruimte: zo stelt de Duitse grondwet bijvoorbeeld dat Religionsunterricht (i.e. confessioneel religieonderwijs) onderdeel is van het reguliere curriculum ${ }^{36}$, waardoor de weinige speelruimte die er bijvoorbeeld in België is, in Duitsland minder evident is. In dat geval zijn andere scenario's allicht realistischer op korte termijn.

\section{Besluit}

Wanneer we het religieonderwijs in Europa in vergelijkend perspectief plaatsen, zien we dat wijzigingen van confessioneel en denominationeel naar niet-confessioneel en niet-denominationeel religieonderwijs nauw verbonden zijn met kerk-staat verhoudingen. In lutherse en anglicaanse landen, waar de kerk lange tijd als overheidsactor instond voor het religieonderwijs, was een deconfessionalisering van het religieonderwijs evidenter dan in katholieke en gemengde landen, waar de $\operatorname{kerk}(e n)$ dit onderwijs op een autonome en onafhankelijke manier organiseren. Een grondige wijziging in het religieonderwijs in laatstgenoemde landen veronderstelt niet alleen verregaande institutionele veranderingen, maar zou ook impliceren dat gevestigde/erkende levensbeschouwingen hun autonomie op het gebied van (religie)onderwijs zouden moeten opgeven. Omdat kerk-staat verhoudingen en daarmee samenhan- 
gende regelgeving op het gebied van religieonderwijs vaak grondwettelijk verankerd zijn of nauw verbonden zijn met een aantal grondrechten (bv. vrijheid van godsdienst; vrijheid van onderwijs; recht op vereniging) zal een deconfessionalisering en secularisering van het religieonderwijs in vele landen niet over een nacht ijs gaan. Hoewel er heel wat argumenten zijn om voor een deconfessionalisering van het religieonderwijs te pleiten (cf. Franken 2017), zijn pragmatische oplossingen soms te verkiezen als second best option en als tijdelijk alternatief. Ook Rome werd niet in één dag gebouwd.

\section{Noten}

1 Deze scholen, waarvoor ik in het vervolg van deze bijdrage voor Nederland de gebruikelijke term 'openbare' scholen zal gebruiken en voor België de gebruikelijke term 'officiële scholen', worden door Maussen en Bader $(2015,3)$ gedefinieerd als "schools to be owed, run, and financed by (a flexible combination of) governmental (federal, state, municipal) authorities".

2 Deze scholen, waarvoor ik in het vervolg van deze bijdrage voor Nederland de gebruikelijke term 'bijzondere' scholen zal gebruiken en voor België de gebruikelijke term 'vrije scholen', worden door Maussen en Bader $(2015,3)$ gedefinieerd als 'schools owned and run by [central or local] organizations or associations whether [partly or fully] publicly financed or not".

3 Cf. Artikel 23 van de Nederlandse grondwet en Artikel 24 van de Belgische grondwet.

4 Grosso modo gaat het zowel in Nederland als in Vlaanderen om zo'n $70 \%$ van alle scholen. In de Franse Gemeenschap (België) ligt dat aantal, met 35\% voor het primair en $57 \%$ voor het secundair onderwijs, beduidend lager. Exacte cijfers voor de Vlaamse Gemeenschap in België zijn te vinden op https://onderwijs.vlaanderen.be/nl/statistisch-jaarboek-van-het-vlaams-onderwijs-2018-2019. Voor de Franse Gemeenschap kan je terecht op http://www.enseignement.be/index.php?page $=23836 \&$ navi $=149$. Voor Nederland zijn er cijfers te vinden op https://www.onderwijsincijfers.nl/ kengetallen/po/instellingen/aantallen-instellingen-po en op https://www.cbs.nl/ nl-nl/nieuws/2017/38/ruim-70-procent-leerlingen-naar-bijzonder-onderwijs. Al deze websites werden geraadpleegd op 25-09-2020.

5 Dit betekent onder meer dat bijzondere scholen in Nederland een eigen wervings- en inschrijvingsbeleid mogen voeren en dus leerkrachten en leerlingen mogen weigeren indien hun toelating niet zou stroken met het pedagogisch project. In België (Vlaanderen) daarentegen moeten alle scholen die door de overheid gesubsidieerd worden toegankelijk zijn voor alle leerlingen, wat hun levensbeschouwelijke overtuiging ook mag zijn. Voorwaarde is wel dat zij (en/of hun ouders) het pedagogisch project van de school ondertekenen.

6 Voor dit onderscheid tussen de vrijheid van stichting, richting en inrichting, zie bv. Lievens 2019, 5-6.

7 In België is het onderwijs niet alleen verzuild georganiseerd, maar is het ook geregionaliseerd, wat betekent dat het autonoom wordt georganiseerd door de Vlaamse, Franse en Duitse Gemeenschap.

8 Anglicaanse godsdienstlessen worden enkel in de Vlaamse Gemeenschap (en dus niet in de Franse en Duitse Gemeenschap) aangeboden. 
9 In de Franse en Duitse Gemeenschappen wordt het vak Niet-confessionele zedenleer door de overheid ingericht. In de Vlaamse Gemeenschap wordt het door de Raad voor Inspectie \& Kwaliteitszorg niet-confessionele Zedenleer (RIKZ), die behoort tot de door de overheid erkende Unie Vrijzinnige Verenigingen (UVV), ingericht en geïnspecteerd.

10 Volgens het actuele federale regeerakkoord (p. 76) zal het boeddhisme als niet-confessionele levensbeschouwing erkend worden door de huidige regering. Dit betekent onder meer dat er in de toekomst ook boeddhistisch onderwijs zal worden aangebeden op de officiële scholen. Zie hiervoor: https://www.belgium.be/sites/default/files/ Regeerakkoord_2020.pdf (geraadpleegd op 19-11-2020).

11 Onder denominationeel religieonderwijs versta ik religieonderwijs dat niet door de overheid, maar door een bepaalde (erkende) religieuze/levensbeschouwelijke instantie of school wordt ingericht. Onder confessioneel religieonderwijs versta ik religieonderwijs dat vertrekt vanuit een bepaalde religieuze traditie en leerlingen in en vanuit die traditie wil socialiseren. Vaak hebben denominationeel en niet-denominationeel religieonderwijs respectievelijk een confessionele en een niet-confessionele insteek, maar dat hoeft niet noodzakelijk zo te zijn.

12 Bij aanvang van het schooljaar vullen ouders een keuzeformulier in, waarin ze aangeven welk levensbeschouwelijk vak hun kind zal volgen. Ook vrijstelling is mogelijk.

13 Zo hebben bijvoorbeeld in Zweden de door de overheid erkende en gesubsidieerde 'bijzondere' scholen, net zoals in België en Nederland, de mogelijkheid om denominationeel en niet-confessioneel religieonderwijs aan te bieden. Omdat deze scholen verplicht zijn om het nationale curriculum te volgen, moeten zij ook een niet-denominationeel vak over religie/levensbeschouwing aanbieden. (cf. Berglund 2021) Ook Denemarken, Noorwegen en het Verenigd Koninkrijk kennen een vergelijkbaar systeem.

14 Uitzonderingen op dit principe vinden we in het departement Alsace Moselle, dat omwille van historische redenen valt onder het concordaat uit 1801 en de organieke wetten uit 1802-1808. Hierdoor zijn er in dit departement momenteel 4 erkende religies (katholicisme, calvinisme, lutheranisme en jodendom) en worden hun afgevaardigden en gebedsleiders door de overheid bezoldigd. Daarnaast wordt er religieonderwijs in de betreffende godsdiensten aangeboden op de openbare scholen en worden de godsdienstleerkrachten door de overheid bezoldigd. Ook in de Franse overzeese gebieden is de wet uit 1905 niet van kracht. Tot slot wordt er ook confessioneel godsdienstonderwijs aangeboden in het Franse private onderwijs, dat goed is voor zo'n 15\% van de scholen, die meestal door de overheid worden gesubsidieerd.

15 Naast deze gesubsidieerde bijzondere scholen die het nationale curriculum volgen, zijn er ook nog enkele private scholen die in beperktere mate door de overheid gesubsidieerd worden en die het nationale curriculum niet volgen.

16 Finland is allicht de meest opvallende uitzondering. Hier zijn zowel de Lutherse als de Orthodox-Christelijke Kerk officiële staatskerken en is het model van denominationeel en confessioneel religieonderwijs op de openbare school geëvolueerd naar een pluralistisch, niet-denominationeel en officieel ook niet-confessioneel model.

17 In deze bijdrage laten we de Oost-Europese landen, die door hun communistisch verleden een specifiek levensbeschouwelijk (onderwijs)landschap hebben, buiten beschouwing. Een actueel overzicht van het religieonderwijs in dit deel van Europa is te vinden in Rothgangel et al. 2020.

18 Deze kaart kwam tot stand in samenwerking met Kristian Niemi, die zowel aan de layout als aan de inhoudelijke input heeft bijgedragen.

19 Een enigszins vergelijkbaar patroon vinden we in het Verenigd Koninkrijk, waar de Anglicaanse Kerk lange tijd als overheidsactor bevoegd was voor het religieonderwijs op de openbare scholen. In 1971/1988 werd het religieonderwijs gedeconfessio- 
naliseerd en werd de bevoegdheid overgedragen naar de Local Education Authorities (LEA). Zie bv. Cush 2011.

20 Doorheen de jaren zijn de privileges voor de Lutherse Kerk wel afgenomen (cf. Kühle 2011) en zowel Zweden als Noorwegen maakten, respectievelijk in 2000 en in 2012 officieel een einde het staatskerk-regime. Deze institutionele wijzigingen vonden echter pas plaats nadat het religieonderwijs al enkele decennia gedeconfessionaliseerd was.

21 Met uitzondering van het departement Alsace-Moselle en de Franse overzeese gebieden. Cf. noot 14 .

22 De meeste Franse scholen zijn openbare scholen, maar zo'n 15\% van alle scholen zijn bijzondere ('private') scholen, die vaak een confessionele grondslag hebben. De meeste van deze scholen hebben een contract met de overheid getekend en worden gedeeltelijk door de overheid gesubsidieerd.

23 Met het oog op deze interlevensbeschouwelijke dialoog heeft de commissie levensbeschouwelijke vakken, in opdracht van de erkende levensbeschouwingen, in 2012 de Interlevensbeschouweljike Competenties (ILC) uitgewerkt. Deze competenties worden door alle erkende levensbeschouwingen onderschreven en moeten volgens Vlaams Decreet in alle levensbeschouwelijke vakken geïmplementeerd worden (cf. BS ०9-032018, te raadplegen op: http://www.ejustice.just.fgov.be/mopdf/2018/03/09_1.pdf\# Page74). De ILC kunnen geraadpleegd worden op: https://www.levensbeschouwelijkevakken.be/interlevensbeschouwelijke-competenties/ (toegang 05-10-2020).

24 Het vak R.K.-godsdienst in de scholen in Vlaanderen (08/07/96). Visietekst van de commissie in opdracht van de bisschoppen. Online beschikbaar via https://www.kuleuven. be/thomas/page/visietekst/ (geraadpleegd op 25-09-2020).

25 Voor een overzicht van de kerndoelen in de onderbouw van het secundair onderwijs zie: http://www.slo.nl/voortgezet/onderbouw/kerndoelen/.

26 Deze zijn: Vereniging van Docenten Levensbeschouwing en Godsdienst (VDLG), Verus, Vereniging van openbare en algemeen toegankelijke scholen (VOS/ABB) en alle docentenopleidingen Godsdienst/Levensbeschouwing.

27 Cf. voetnoot 9 .

28 Deze regelgeving geldt enkel voor het officieel onderwijs. Voor het vrij - hoofdzakelijk katholiek - onderwijs geldt dat scholen zelf kiezen op welke manier het 'recht op levensbeschouwelijk onderwijs ten laste van de gemeenschap' in de kleuterschool concreet wordt ingevuld.

29 Sinds 2008 pleit ik, samen met Patrick Loobucyk, voor de invoering van een nieuw, door de overheid georganiseerd vak over levensbeschouwingen, waarin ook aandacht is voor filosofie en burgerschap (vandaar de naam 'LEF': Levensbeschouwing - Ethiek - Filosofie). Het voorstel om zo een vak in alle onderwijsnetten in te richten werd uitgewerkt in verschillende academische publicaties (zie bv. Loobuyck \& Franken 2009; Loobuyck \& Franken 2013; Loobyuck 2014; Franken 2017b, 127-144; Franken 2018, 145-147) en opiniestukken en werd opgepikt door een aantal politieke partijen. Om een dergelijk vak in te voeren ter vervanging van de huidige levensbeschouwelijke vakken, is een herziening van art.24 van de grondwet echter noodzakelijk. In 2019 stemde het parlement voor een mogelijke herziening van dit artikel, maar deze mogelijkheid werd tegengehouden door de senaat, die met een ex-aequo van 23 stemmen voor en 23 stemmen tegen stemde. Dit betekent dat het status quo voorlopig zal blijven en dat, op zijn minst voor de komende acht jaar, andere 'creatieve' mogelijkheden die kaderen binnen de grondwet, de enige optie zijn.

30 Online beschikbaar via: https://www.wallonie.be/sites/default/files/2019-09/declara tion_politique_regionale_2019-2024.pdf (geraadpleegd op 25-09-2020).

31 Raad van State, de Pascale nr. 5885, 12-03-2015. 
32 Vlaams Regeerakkoord 2019-24, p. 23, zie ook p. 13. Online beschikbaar via: http:// docs.vlaamsparlement.be/docs/varia/regeerakkoord-2019-2024.pdf (geraadpleegd op 25-09-2020).

33 Het laatste woord over burgerschapsonderwijs in Nederland is overigens lang nog niet gezegd: zo diende huidig minister van Onderwijs en Media Arie Slob in 2019 een wetsvoorstel 'Wijziging van een aantal onderwijswetten in verband met verduidelijking van de burgerschapsopdracht aan scholen in het funderend onderwijs' in, dat momenteel in behandeling is bij de Tweede Kamer. Het voorstel, (online geraadpleegd op 16-112020 via: https://www.eerstekamer.nl/wetsvoorstel/35352_verduidelijking_van_de) wil meer duidelijkheid verschaffen "over de algemene burgerschapsdoelstelling van het onderwijs en de uitgangspunten die daarbij gelden." Daarnaast beoogt het voorstel "een meer verplichtend karakter op het gebied van burgerschap", de ontwikkeling van "bouwstenen die de specifieke kennis en vaardigheden van leerlingen beschrijven" en wil het voorzien in "een zorgplicht voor het bevoegd gezag ten aanzien van de schoolcultuur".

34 Het Gemeenschapsonderwijs of GO! is het onderwijs dat wordt ingericht en gesubsidieerd door de Vlaamse Gemeenschap en is op dit moment de grootste onderwijsverstrekker binnen het officiële net. Naast het GO! behoren ook het gemeentelijk, stedelijk en provinciaal onderwijs tot het officiële net. Scholen die hiertoe behoren, worden respectievelijk opgericht door gemeenten, steden en provincies.

35 https://www.kerknet.be/kerknet-redactie/persbericht/erkende-instanties-over-inter religieuze-dialoog-3de-graad-go

36 Art. 7, \2 en 3 van de Duitse grondwet luiden als volgt:

(『2) Die Erziehungsberechtigten haben das Recht, über die Teilnahme des Kindes am Religionsunterricht zu bestimmen.

( $(3)$ Der Religionsunterricht ist in den öffentlichen Schulen mit Ausnahme der bekenntnisfreien Schulen ordentliches Lehrfach. Unbeschadet des staatlichen Aufsichtsrechtes wird der Religionsunterricht in Übereinstimmung mit den Grundsätzen der Religionsgemeinschaften erteilt. Kein Lehrer darf gegen seinen Willen verpflichtet werden, Religionsunterricht zu erteilen (mijn cursivering).

\section{Literatuur}

Alberts, Wanda (2019),

Religious Education as Small 'i' Indoctrination: How European Countries Struggle with a Secular Approach to Religion in Schools, in: CEPS Journal, 9 (4), 53-72. DOI: https://doi.org/10.26529/cepsj.688.

Alii, E. T. (2009),

Godsdienstpedagogiek. Dimensies en spanningsvelden, Zoetermeer: Meinema.

Andreassen, Bengt-Ove (2013),

Religion Education in Norway: Tension or Harmony between Human Rights and Christian Cultural Heritage?, in: Temenos, 49 (2), 137-164. DOI: https://doi.org/ 10.33356/temenos.9544. 
Beemsterboer, Marieke (2011),

Geloven in Onderwijs. Het kennisgebied geestelijke stromingen in het Nederlands basisonderwijs, in: Tijdschrift voor Religie, Recht en Beleid, 2 (3), 17-30.

Berglund, Jenny (2013),

Swedish religion education: Objective but Marinated in Lutheran Protestantism?, in:

Temenos, 49 (2), 165-184. DOI: https://doi.org/10.33356/temenos.9545.

Berglund, Jenny (in druk),

Islamic Religious Education and Education about Islam in Sweden, in: Franken, Leni \& Bill Gent (eds.), Islamic Religious Education in Europe, London/New York: Routledge. Braem, François (2018),

La Mise en Place du Cours Commun "Vie et Société": Mise à Mort ou Réintégration du Facteur Religieux? Le Cas du Grand-Duché du Luxembourg, in: Citoyenneté à l'Ecole: avec ou sans Convictions? Approches Européennes. Etterbeek: Bepax, 61-75. Available from : http://www.bepax.org/files/files/OUTILS/bepax-etude-citoyennete-769-a-7681-e-769-cole-03.pdf (accessed 2020-09-24).

Buchardt, Mette (2014),

Religious Education at Schools in Denmark, in: Rothgangel, Martin, Geir Skeie \& Martin Jäggle (eds.), Religious Education at Schools in Europe, part 3: Northern Europe, 45-74. Vienna: Vienna University Press. DOI: https://doi.org/10.14220/9783737002738.45.

Buchardt, Mette (2015),

Cultural Protestantism and Nordic Religious Education: An Incision in the Historical Layers behind the Nordic Welfare State Model, in: Nordidactica - Journal of Humanities and Social Science Education, (2), 131-165. Available from: https://journals.lub.lu.se/ nordidactica/article/view/19003 (accessed 2020-09-24).

Congregation for Catholic Education (2009), in:

Circular Letter to the Presidents of Bishops' Conferences on Religious Education in Schools. Available from: http://www.vatican.va/roman_curia/congregations/ccatheduc/ documents/rc_con_ccatheduc_doc_20090505_circ-insegn-relig_en.html (Accessed 2020-09-24).

Cush, Denise (2011),

Without Fear or Favour: Forty Years of Non-confessional and Multi-faith Religious Education in Scandinavia and the UK, in: Franken, Leni \& Patrick Loobuyck (eds.), Religious Education in a Plural, Secularised Society. A Paradigm Shift, Münster: Waxmann, 69-84.

Davidsen, Markus Altena (2020), Voorstel basiscurriculum Levensbeschouwing en Religie, in: Narthex, 15-26.

Davidsen, Markus Altena, Jeanette den Ouden, Taco Visser \& Marleen Lammers (2017), Religie en Levensbeschouwing: Rationale voor een Kerncurriculum vo, in: Narthex 17 (1), 17-26. 
De Vlaamse Bisschoppen en de Erkende Instantie r.-k. godsdienst (2017),

Het vak r.-k. godsdienst op het kruispunt van samenleving, onderwijs \& kerkgemeenschap. Online beschikbaar via https://www.kuleuven.be/thomas/page/vakgodsdienst-kruispunt-samenleving-onderwijs-kerkgemeenschap/\#noot4 (geraadpleegd op 25-09-2020).

Dijk-Groeneboer, Monique C.H. van (2017),

Religious Education in the Secularised Netherlands, in: International Studies in Catholic Education, 9 (1), 17-28. DOI: https://doi.org/10.1080/19422539.2017.1286907.

Franken, Leni (2016),

Liberal Neutrality and State Support for Religion, Zürich: Springer.

Franken, Leni (2017),

Coping with Diversity in Religious Education: an Overview, in: Journal of Beliefs and Values: Studies in Religion and Education, 38 (1), 105-120. DOI: https://doi.org/10.1080/ ${ }_{13} 617672.2016 .1270504$.

Franken, Leni (2017),

Geld voor je God? De financiering van Levensbeschouwingen in België, Brussel: University Press of Antwerp.

Franken, Leni (2018),

Vrijheid van Godsdienst en Onderwijs 2.0: Feit of Fictie?, in: Geerinck, Ilse \& Ruth Wouters (red.), Een Deliberatie over Onderwijsvrijheid, Leuven: Lannoo Campus, 136-147.

Gaudin, Philippe (2017),

Neutrality and Impartiality in Public Education: the French Investment in Philosophy, Teaching about Religions, and Moral and Civic Education, in: British Journal of Religious Education 39(1), 93-106. DOI: https://doi.org/10.1080/01416200.2016.1218221.

Grimmitt, Michael (1987),

Religious Education and Human Development, Great Britain: McCrimmon.

Jensen, Tim (2019),

'Jensen's Scientific Approach' to Religion Education, in: CEPS Journal, 9 (4), 31-51. DOI: https://doi.org/10.26529/cepsj.707.

Kjeldsen, Karna (2019),

A Study-of-Religion(s)-Based Religion Education: Skills, Knowledge, and Aims, in: CEPS Journal, 9 (4), 11-29. DOI: https://doi.org/10.26529/cepsj.678.

Kühle, Lene (ed.) (2011),

Legal Regulation Of Religion In The Nordic Countries - special journal issue of Nordic Journal of Religion and Society, 24 (2). Available from: https://www.idunn.no/nordic_ journal_of_religion_and_society/2011/02 (accessed 30 April 2020). 
Lievens, Johan (2019),

De vrijheid van onderwijs, Antwerpen: Intersentia.

Loobuyck, Patrick (2014),

Meer LEF in het Onderwijs. Levensbeschouwing, Ethiek en Filosofie voor Iedereen, Brussel: VUBPress.

Loobuyck, Patrick \& Leni Franken (2009),

Het schoolpactcompromis in vraag gesteld: pleidooi voor een nieuw vak over levensbeschouwingen en filosofie in het Vlaams onderwijs, in: Tijdschrift voor onderwijsrecht en onderwijsbeleid, 10 (1-2), 44-64.

Loobuyck, Patrick \& Leni Franken (2013),

Waarheen met de levensbeschouwelijke vakken in Vlaanderen? in: Pedagogiek, 33 (2), 103-118.

Maussen, Marcel \& Veit Bader (2015),

'Non-governmental Religious Schools in Europe: Institutional Opportunities, Associational Freedoms, and Contemporary Challenges, in: Comparative Education, 51 (1), 1-21. DOI: https://doi.org/10.1080/03050068.2014.935581.

Rota, Andrea (2015),

État des Lieux des Politiques de l'Enseignement Religieux en Suisse Latine. Réformes Institutionnelles et Schémas Interprétatifs, Lausanne: Infolio (Collection "CULTuREL" 6, Swiss Society for the Study of Religion).

Rothgangel, Martin, Yauheniya Danilovich \& Martin Jäggle (eds) (2020),

Religious Education in Europe. Part 4: Eastern Europe, Vienna: Vienna University Press. Van den Kerckhove, Anna (2014),

Teaching about Religious Issues within the Framework of French 'laïcité', in: Franken, Leni \& Patrick Loobuyck (eds), Religious Education in a Plural, Secularised Society. A Paradigm Shift, Münster: Waxmann, 55-68.

Vermeer, Paul \& Leni Franken (2018),

Naar niet-confessioneel levensbeschouwelijk onderwijs in een verzuild onderwijsstelsel, Pedagogiek, 38 (3), 287-312. DOI: 10.5117/PED2018.3.002.VERM.

Willaime, Jean-Paul (2014),

Religious Education in French Schools, in: Rothgangel, Martin, Robert Jackson \& Martin Jäggle (eds), Religious Education at Schools in Europe. Part 2: Western Europe. Vienna: Vienna University Press, 99-120. DOI: https://doi.org/10.14220/ 9783737002684.99 